\title{
Race specificity of stripe rust resistance in relation to susceptibility of Egyptian wheat cultivars
}

\section{Shahin A A • Draz I S* Esmail Samar M}

Received: 20 May 2020 / Accepted: 12 June 2020 / Published online: 14 August 2020

(C) Egyptian Phytopathological Society 2020

\begin{abstract}
$\mathbf{R}$ ace - specific resistance of stripe rust caused by Puccinia striformis f. sp. tritici (Pst) in relation to susceptibility of Egyptian wheat cultivars were investigated during two growing seasons 2017/18 and 2018/19 in Egypt. High levels of adult plant susceptibility were recorded in the second season in comparison with that of the first season. Out of 20 cultivars tested, susceptibility (S) up to $80 \mathrm{~S}$ was recorded with only 8 cultivars and 4 resistance genes $(\mathrm{Yr})$ in the first season. However, it was recorded with 14 cultivars (reached $90 \mathrm{~S}$ ) and $7 \mathrm{Yr}$ genes (up to $80 \mathrm{~S}$ ) in the second one. The highest susceptibility was recorded with Sids-12 and Gemmeiza-11 (90 S), followed by Misr-1 (80 S), Misr-2 (70 S), Giza-163 (60 S), $Y r 7$ and $Y r 9$ (80 S). Cultivars, Misr-1, Misr-2, Gemmeiza-5, Gemmeiza-12, Giza-167, and Shandweel-1, exhibiting moderate resistance (MR) in the first season, lost their resistance in the second one. Nine $Y r$ genes $Y r 2, \quad Y r 4, \quad Y r 6, Y r 7, \quad Y r 8, Y r 9, \quad Y r 10, Y r 25, \quad Y r 27, \quad Y r 32$ and $Y r S p$ were postulated in cultivars through multipathotyping with the prevailing $P s t$ races in Egypt, 64E0, 0E16, 66E0, 4E130, 2E0, 2E16, 4E0, 6E4, 70E4, PstS2, $P s t S 3$ and Triticale aggressive. Only $Y r 9$ was present in 7 susceptible cultivars, Sids-13, Gemmeiza-7, Gemmeiza-9, Gemmeiza-10, Gemmeiza11, Gemmeiza-12, and Shandweel-1. A molecular assay using the STS marker iag95 validated the presence of $\operatorname{Yr} 9$ in the last-mentioned cultivars. Cultivars may have become susceptible due to the virulence to $\mathrm{Yr} 9$ gene, which should be restricted to use alone in wheat production.
\end{abstract}

Keywords: Triticum aestivum, Puccinia striiformis, Resistance genes, Cultivar susceptibility, Race specificity.

\section{* Correspondence: Draz I S \\ dr.ibrahim_draz@yahoo.com}

\section{Shahin A A}

Wheat Disease Research Department, Plant Pathology Research Institute, Agricultural Research Center, 12619 Giza, Egypt

\section{Draz IS}

Wheat Disease Research Department, Plant Pathology Research Institute, Agricultural Research Center, 12619 Giza, Egypt

\section{\Esmail Samar M}

Wheat Disease Research Department, Plant Pathology Research Institute, Agricultural Research Center, 12619 Giza, Egypt

\section{Introduction}

Stripe (yellow) rust disease caused by Puccinia striiformis West. f. sp. tritici (Pst) is a major threat to wheat production worldwide (Chen et al., 2014; Kumar et al., 2016), particularly in temperate, humid and cooler wheat-growing regions of the world (Chen, 2005). Up to $88 \%$ of the world's wheat cultivars had become susceptible since 1960 and that annual loss amounted to 5.47 million tonnes (Beddow et al., 2015). Grain yield losses of 10 to $70 \%$ have been recorded in most wheatproducing areas of the world, which varies with the cultivar susceptibility, initial infection, disease period and development rate (Chen 2005). In Egypt, the disease affected most of the wheat cultivars, since major epiphytotic has been recorded once in every decade since the Sixties, causing grain yield loss ranged from $14 \%$ to $26 \%$ in the Nile Delta region and 10\% loss countrywide (El-Daoudi et al., 1996). Draz et al. (2018) reported grain weight loss of up to $23.12 \%$ (Giza-160) in Egypt. The 
most economical and eco-friendly approach to control the disease is the use of resistant wheat varieties (Pink, 2002; Chen, 2013; Yang et al., 2019). Breeding programs for disease resistance mainly aim to provide host materials with combinations of effective resistance genes concerning the prevalent population of the pathogen. Usually, selection breeding for resistance is solely based on field evaluations, while the precise constitution of the gene involved in the resistant germplasm is little known.

It is a challenge to avoid stripe rust epidemics in Egypt due to numerous wheat cultivars without genetic information that have been released and cultivated countrywide. Those cultivars may consist of the same gene or combined genes for resistance which may lead up to pressure the selection for corresponding virulence races. Therefore, identifying the resistance genes in wheat cultivars is essential for the development of cultivars with effective genes to control the disease. To date, 80 resistance genes of stripe rust $(\mathrm{Yr})$ have been permanently named in wheat (McIntosh et al., 2017; Feng et al., 2018; Nsabiyera et al., 2018; Long et al., 2019), out of them, $67 \mathrm{Yr}$ genes have been temporarily designated, including seedling resistance (all-stage resistance) and adult plant resistance (APR) (Wang and Chen, 2017). Among these, Yr11, Yr12, Yr13, Yr14, Yr16, Yr18, Yr29, Yr30, Yr34, Yr36, Yr39, Yr46, Yr48, Yr52 and Yr67 confer adult plant resistance, whereas the others confer all-stage resistance (race-specific resistance) e.g $\mathrm{Yr} 2, \mathrm{Yr} 4, \mathrm{Yr} 5, \mathrm{Yr} 6, \mathrm{Yr} 7, \mathrm{Yr} 8, \mathrm{Yr} 9, \mathrm{Yr} 10$, Yr15, Yr17, Yr19, Yr25, Yr26, Yr27, Yr28, Yr35, Yr36, $Y r 37, Y r 38, Y r 40, Y r 42 Y r 53, Y r 61, Y r 65$ and $Y r 69$ (Chen, 2005; Zheng et al., 2017). Of these, only $Y r 5$ and $Y r 15$, Yr53, Yr61, Yr65, and Yr69 still confer resistance to most Pst races and can be used in breeding for disease resistance (Xu et al., 2013; Zeng et al., 2014; Zhou et al., 2014; Yang et al., 2016; Shahin, 2017). Even though these $\mathrm{Yr}$ genes have been detected in various wheat varieties, but their efficacy against the diverse Pst pathotypes is limited due to the race specificity of allstage resistance. By contrast, APR is generally considered long-lasting, but its known genes represent a minority (Chen, 2005; Ellis et al., 2014; Kankwatsa et al., 2017).

Epidemiological concerns suggest that it should deploy different resistance genes in wheat cultivars for controlling wheat stripe rust in the affected regions (Wan et al., 2007; Zeng, 2014). Therefore, a further survey of cultivar susceptibility along with race specificity of seedling resistance genes in local wheat cultivars could provide information concerning the epidemiology and evolution of different populations of the pathogen and its responsibility in the cultivar susceptibility. To apply this approach, it is important to know which resistance genes are already existed in cultivars and being used in breeding programs in the epidemiological regions.

Screening of resistance genes through multipathotypic inoculation test (known as gene postulation) with a set of virulent $(A v) /$ virulent $(v)$ races of the pathogen is an effective approach to determine which genes are existed in wheat cultivars (Browder and Eversmeyer, 1980; Statler, 1984; Wang et al., 2009), which it has been used since the discovery of the gene-for-gene concept by Flor (1959). The approach relies on the interaction between the gene of the host lines and $A v / v$ gene of pathogen races to determine the probable resistance genes in wheat cultivars. Several researchers have employed gene postulation for identifying $\mathrm{Yr}$ genes in a group of wheat genotypes (Sharma et al., 1995; Hovmøller, 2007; Xia et al., 2007; Dawit et al., 2012; El Amil et al., 2019). Also, the development of molecular markers has led to efficient methods of plant breeding for disease resistance, which is a reliable method in identifying resistance genes in wheat. DNA markers, such as restriction fragment length polymorphism (RFLP), amplified fragment length polymorphism (AFLP), simple-sequence-repeat (SSR), and sequence-tagged site (STS) have been widely used in conjugation with pedigree information and gene postulation to identify $\mathrm{Yr}$ resistance genes in wheat cultivars and advanced breeding lines (Wang et al., 2009; Zhou et al., 2014; Zeng et al., 2014; Gebreslasie et al., 2020). In the present study, we report race-specific resistance genes $(Y r)$ responsible for the susceptibility of Egyptian wheat cultivars using the gene-for-gene theory and molecular marker to verify the $Y r$ gene(s) postulated in cultivars.

\section{Materials and methods}

\section{Plant materials}

Twenty Egyptian wheat cultivars (Table 1) were tested for adult plant susceptibility to stripe rust and the presence/absence of stripe rust race-specific resistance genes. In this study, nine race-specific resistance genes $Y r 2, Y r 4, Y r 6, Y r 7, Y r 8, Y r 9, Y r 10, Y r 25$, and $Y r 27$, corresponding to virulence spectra of the contemporary Egyptian population of $P$. striiformis f. sp. tritici during 
the respective period (2016-2018) were selected. The tested genes in Kalyasona (Yr2), Hybrid-46 (Yr4), TP1295 (Yr25), near-isogenic lines (NILs) in Avocet (AOC) with $Y r 6, Y r 7, Y r 8, Y r 9, Y r 10, Y r 27$, were kindly provided by CIMMIYT, Mexico.

\section{Pst races}

Twelve $P s t$ races, 64E0, 0E16, 66E0, 4E130, 2E0, 2E16, 4E0, 6E4, 70E4, PstS2, PstS3 and Triticale aggressive reported in our previous study during 2016-2018 in Egypt (Draz et al., 2019; Draz, 2019) were used in this study. The 12 Pst races have virulence spectra to the tested $\mathrm{Yr}$ genes as shown in Table (2).

\section{Evaluation of adult plant susceptibility}

In the open field, the adult plant susceptibility of the tested wheat cultivars and $\mathrm{Yr}$ genes (Table 1) to stripe rust was evaluated under natural infection. The experiments were carried out during two growing seasons (2017/18 and 2018/19) at the Experimental Farms of Sakha Agricultural Research Station, Agricultural Research Center, Egypt. A triple experiment was performed in a complete randomized block. The sowing date was in mid-November. Seeds of the tested cultivars/lines were sown in $3 \mathrm{~m}$ long rows (3 rows/plot per cultivar) with $30 \mathrm{~cm}$ apart and $5 \mathrm{~g}$ seed per row. The experiment was surrounded by a $1.5 \mathrm{~m} 2$ belt of the susceptible variety Morocco served as a spreader of natural infection and susceptible check. All cultural practices recommended for the wheat crop were applied. Adult plant susceptibility to wheat stripe rust was assessed at the early dough stage (Large 1954) when rust symptoms have fully developed in comparison with the susceptible check cultivar Morocco. Disease assessment was scored based on host responses as described in Table (3) according to Roelfs et al. (1992) along with rust severity expressed as percentage coverage of leaves with rust pustules following Cobb's scale modified by Peterson et al. (1948).

Table 1 Egyptian wheat cultivars used in this study and their pedigree

\begin{tabular}{|c|c|}
\hline Cultivar & Pedigree \\
\hline Misr-1 & OASIS/SKAUZ//4*BCN/3/2*PASTOR.CMSSOYO1881T-050M-030Y-O3OM-030WGY-33M-0Y-0S \\
\hline Misr-2 & SKAUZ/BAV92.CMSS96M0361S-1M-010SY-010M-010SY-8M-0Y-0S \\
\hline Misr-3 & CMSS06Y00582T099TOPM-099Y-099ZTM-009Y-099M-10WGY-0B-0EGY \\
\hline Sids-12 & BUC//7C/ALD/5/MAYA74/ON//1160-147/3/BB/GLL/4/CHAT"S"/6/MAYA/VUL//CMH74A.630/4*SX \\
\hline Sids-13 & KAUZ "S"//TSI/SNB"S". ICW94-0375-4AP-2AP-030AP-0APS-3AP-0APS-050AP-0AP-0SD \\
\hline Sakha-61 & Inia-RL4220//7C/YR “'S” CM15430-25-55-0S-0S \\
\hline Sakha-93 & Sakha92/TR810328S8871-1S-2S-1S-0S \\
\hline Sakha-94 & Opata/Rayon//Kauz CMBW9043180-OTOPM-3Y-010M-010M-010Y-10M-015Y-0Y-0AP-0S \\
\hline Sakha-95 & CMA01Y00158S-040POY-040M-030ZTM-040SY-26M-0Y-0SY-0S \\
\hline Gemmeiza-5 & Vee"S"/SWM6525GM.4017-1GM.7GM-3GM-0GM \\
\hline Gemmeiza-7 & CMH74A.630/SX//SER182/3/AGENT. GM4611-2GM-3GM-1GM-0GM \\
\hline Gemmeiza-9 & ALD"S"/HUAC"S"//CMH74A.630/SX. GM4583-5GM-1GM-0GM \\
\hline Gemmeiza-10 & Maya74“'S',/on/1160-147/3/Bb/G11/4/chat“'S',/5/crow“'S’'CG5820-3G-1G-2G-0G \\
\hline Gemmeiza-11 & BOW “'S”/KVZ “'S”//7C/SERI82/3/GIZA168/SKHA61 \\
\hline Gemmeiza-12 & OTUS/3/SARA/THB//VEECMSS97Y00227S-5Y-010M-010Y-010M-2Y-1M-0Y-0GM \\
\hline Giza-163 & T. aestivum/Bon//Cno/7CCM33009-F-15M-4Y-2M-1M-1M-1Y0M \\
\hline Giza-167 & Au/UP301//G11/SX/Pew“'S”/4/Mai“'S”/May“'S”//Pew“'S”CM67245-C-1M-2Y-1M-7Y-1M-0Y \\
\hline Giza-168 & MRL/BUC//Seri.CM93046-8M-0Y-0M-2Y-0B \\
\hline Giza-171 & Sakha93/Gemmeiza9S.6-1GZ-4GZ-1GZ-2GZ-0S \\
\hline Shandweel-1 & SITE//MO/4/NAC/TH.AC//3*PVN/3/MIRLO/BUC.CMSS93B00567S-72Y-010M-010Y-010M-0HTY \\
\hline
\end{tabular}




\section{Multipathotypic test}

To postulate stripe rust race-specific resistance genes $(Y r)$ in wheat cultivars, the gene-for-gene concept for infection type data was applied according to the method of Browder and Eversmeyer (1980) and Statler (1984). In this test, multipathotyping was carried out to the tested wheat accessions through the inoculation with the 12 races of $P$. striiformis f.sp. tritici used in this study. In which, 8-day-old seedlings of wheat cultivars/lines were inoculated with urediniospores of each Pst race according to the method described by Stubbs (1988). The inoculated seedlings were misted with water and incubated in a dark dew chamber at $10^{\circ} \mathrm{C}$ for $24 \mathrm{~h}$ under high relative humidity (RH). After incubation, the inoculated seedlings were transferred to a greenhouse with conditions of $100 \% \mathrm{RH}$ and $13 \pm 2^{\circ} \mathrm{C}$ under $16 \mathrm{~h}$ photoperiod with a light intensity of $100 \mu \mathrm{mol} \mathrm{m} \mathrm{m}^{-2} \mathrm{sec}^{-}$ Experiments were performed in three replications in the greenhouse at the Wheat Disease Research Department, Sakha Agricultural Research Station of Egypt. Disease scoring was made 15-18 days after inoculation. First seedling leaf was considered for phenotyping on a 0-9 scale (McNeal et al., 1971), where infection types 0 to 6 refer to resistant and 7 to 9 susceptible.

Table 2 The prevailing races of $P$. striiformis f. sp. tritici (Pst) in Egypt during 2016-2018 used in this study and their virulence spectra to the tested stripe rust race-specific genes (Yr)

\begin{tabular}{|c|c|}
\hline Pst race & Virulence spectra \\
\hline 0E16 & $Y r 8$ \\
\hline $2 \mathrm{E} 0$ & $\operatorname{Yr} 7$ \\
\hline $4 \mathrm{E} 0$ & $\operatorname{Yr} 2, \operatorname{Yr} 6$ \\
\hline $64 \mathrm{E} 0$ & Yr4 \\
\hline $66 \mathrm{E} 0$ & $Y r 4, Y r 7$ \\
\hline $70 \mathrm{E} 4$ & $\operatorname{Yr} 2, Y r 4, Y r 6, Y r 7$ \\
\hline $6 \mathrm{E} 4$ & $\operatorname{Yr} 2, \operatorname{Yr} 6, \operatorname{Yr} 7, \operatorname{Yr} 25$ \\
\hline $2 \mathrm{E} 16$ & $\operatorname{Yr} 7, \operatorname{Yr} 8$ \\
\hline 4E130 & $\operatorname{Yr} 2, \operatorname{Yr} 6, \operatorname{Yr} 7, \operatorname{Yr} 25$ \\
\hline PstS2 & $\operatorname{Yr} 2, \operatorname{Yr} 6, \operatorname{Yr} 7, \operatorname{Yr} 8, \operatorname{Yr} 9, \operatorname{Yr} 25, \operatorname{Yr} 27$ \\
\hline PstS3 & Yr2, Yr6, Yr7, Yr8, Yr25 \\
\hline Triticale aggressive & $\operatorname{Yr} 2, \operatorname{Yr} 6, \operatorname{Yr} 7, \operatorname{Yr} 8, \operatorname{Yr} 10$ \\
\hline
\end{tabular}

Table 3 Adult plant infection types of wheat stripe rust used in disease assessment

\begin{tabular}{|c|c|c|}
\hline $\begin{array}{c}\text { Infection } \\
\text { type }\end{array}$ & $\begin{array}{c}\text { Host } \\
\text { response }\end{array}$ & Disease symptoms \\
\hline $\mathbf{0}$ & Immune & $\begin{array}{l}\text { No uredia or other } \\
\text { symptoms of disease } \\
\text { infection }\end{array}$ \\
\hline $\mathbf{R}$ & Resistant & $\begin{array}{l}\text { Uredia minute surrounded } \\
\text { by distract necrotic area }\end{array}$ \\
\hline MR & $\begin{array}{l}\text { Moderately } \\
\text { Resistant }\end{array}$ & $\begin{array}{l}\text { Uredia small to medium } \\
\text { usually in green islands } \\
\text { surrounded by necrotic or } \\
\text { chlorotic tissue }\end{array}$ \\
\hline MS & $\begin{array}{l}\text { Moderately } \\
\text { Susceptible }\end{array}$ & $\begin{array}{l}\text { Uredia medium in size } \\
\text { with no necrosis but } \\
\text { chlorosis may be present }\end{array}$ \\
\hline $\mathbf{S}$ & Susceptible & $\begin{array}{l}\text { Uredia large with no } \\
\text { necrosis but chlorosis }\end{array}$ \\
\hline
\end{tabular}

\section{Molecular marker assay}

The stripe rust resistance genes postulated in the wheat cultivars based on infection types to Pst races were verified to be present based on gene-specific molecular markers. In this assay, the STS marker iag95 with primer sequence fwd 5' CTCTGTGGATAGTTACTTGATCGA 3', rev 5' CCTAGAACATGCATGGCTGTTACA 3', was used to verify $\mathrm{Yr} 9$ in cultivars (Mago et al., 2002). Genomic DNA was extracted from the fresh leaves using a Cetyl Trimethyl Ammonium Bromide (CTAB) protocol according to Doyle and Doyle (1987). Purification and quantification of DNA were determined via UV spectrophotometer measurement (Pharmacia, Biotech., Ultrospec 1000). The DNA samples were diluted for a final concentration of $10 \mathrm{ng} / \mu \mathrm{l}$. Master Mix (Dream Taq Green PCR Master Mix (2X), Thermo Scientific), containing PCR reagents (dNTPs $0.4 \mathrm{mM}$ each, 2X Taq DNA polymerase and $4 \mathrm{mM} \mathrm{MgCl} 2$ ) was used for PCR reaction. A total PCR reaction volume of $25 \mu \mathrm{l}(12.5 \mu \mathrm{l}$ of Master Mix, $0.8 \mu \mathrm{l}$ of forward/reverse primer, $2 \mu \mathrm{l}$ of DNA template, $9.7 \mu \mathrm{l}$ sterile distilled water) was performed in a PCR condition (Techne, PROGENE Thermocycler) of $94^{\circ} \mathrm{C} 3 \mathrm{~min}$ (1 cycle), $94^{\circ} \mathrm{C} 30 \mathrm{~s}, 55^{\circ} \mathrm{C} 60 \mathrm{~s}, 72^{\circ} \mathrm{C} 70 \mathrm{~s}(30$ cycles $), 25{ }^{\circ} \mathrm{C} 60 \mathrm{~s}$ (1 cycle), according to the method described by Mago et al. (2002) with some modifications. PCR amplification products of $10 \mu \mathrm{l}$ each sample were electrophoresed in $1.5 \%$ agarose gel stained with ethidium bromide at 100 $\mathrm{V}$ for about 20 min. A $100 \mathrm{bp}$ DNA ladder H3 RTU, Nippon Genetics Europe $\mathrm{GmbH}$, served in calibration. DNA bands were visualized using a UV-transilluminator (Herolab UVT 2020, Kurzwellig), then photographed. 


\section{Results}

\section{Adult plant susceptibility}

Field data showed in Table 4 for adult plant reaction of wheat accessions against stripe rust revealed that the level of susceptibility in the 2018/19 growing season was higher than that observed in the 2017/18 growing season. Out of 20 cultivars and 9 wheat lines tested, susceptibility (S) was recorded with 14 Egyptian cultivars (Misr-1, Misr-2, Sids-12, Sids-13, Sakha-61, Gemmeiza-5, Gemmeiza-7, Gemmeiza-9, Gemmeiza-10, Gemmeiza-11, Gemmeiza-12, Giza-163, Giza-167, Shandweel-1) ranging between $30 \mathrm{~S}-90 \mathrm{~S}$, and 7 wheat lines with $Y r$ genes $Y r 2, Y r 6, Y r 7, Y r 8, Y r 9, Y r 25, Y r 27$ (20 MS-80 S) in 2018/19 growing season. However, it was recorded with only 8 cultivars, Sids-12, Sids-13, Sakha-61, Gemmeiza-7, Gemmeiza-9, Gemmeiza-10, Gemmeiza-11, Giza-163 and 4 lines with resistance genes $\mathrm{Yr} 6, \mathrm{Yr} 7, \mathrm{Yr} 9, \mathrm{Yr} 27(10 \mathrm{~S}-80 \mathrm{~S})$ in $2017 / 18$ growing season. The highest level of susceptibility reaching $90 \mathrm{~S}$ was recorded with Egyptian cultivars, Sids-12 and Gemmeiza-11, followed by Misr-1 (80 S), Misr-2 (70 S), and Giza-163 (60 S) in 2018/19 growing season. However, it was up to $80 \mathrm{~S}$ in the $2017 / 18$ growing season with only one cultivar Sids-12. Regarding wheat lines, $Y r 7$, and $Y r 9$ showed the highest level of susceptibility $(80 \mathrm{~S})$, followed by $\operatorname{Yr} 6(60 \mathrm{~S})$ in the second season, while it was $80 \mathrm{~S}, 60 \mathrm{~S}$, and $40 \mathrm{~S}$, respectively in the previous season 2017/18. Wheat cultivars, Misr-1 (rated Tr MR), Misr-2 ( $\operatorname{Tr} R$ ), Gemmeiza-5, Gemmeiza-12 (10 MR), Giza-167 and Shandweel-1 (30 MR), exhibiting resistance in 2017/18 growing season, lost their resistance in the second growing season (2018/19), rating susceptibility of $80 \mathrm{~S}$, $70 \mathrm{~S}, 30 \mathrm{~S}, 40 \mathrm{~S}, 30 \mathrm{~S}, 70 \mathrm{~S}$, respectively. Likewise, the resistance of $\operatorname{Yr} 8$ (5 MR), $Y r 2$ and $\operatorname{Yr} 25$ (10 MR) observed in the first season, had been lost in the second season exhibiting moderate susceptible (20 MS) in $Y r 2$ and $Y r 8$, and susceptible (30 S) in $Y r 25$. Both $Y r 4$ and Yrl0 were still without symptoms of disease infection during both seasons. It was also observed that wheat cultivars, Misr-3, Sakha-93, Sakha-94, Sakha-95, Giza168 and Giza-171 still be resistant during both growing seasons rating moderately resistance (MR).

\section{Gene postulation and molecular marker}

Data in Table 5 list the tested cultivars/lines with their seedling respective response spectra to 12 Pst races under greenhouse conditions. The results for each cultivar were interpreted based on the race-specific responses on the lines. Out of nine $Y r$ genes tested, spectra appeared to represent the only $Y r 9$ to be postulated in eight Egyptian wheat cultivars, Sids-13, Sakha-94, Gemmeiza-7, Gemmeiza-9, Gemmeiza-10, Gemmeiza-11, Gemmeiza-12, and Shandweel-1. The presence of the $\mathrm{Yr} 9$ gene in nine Egyptian wheat cultivars, Sids-13, Sakha94, Sakha-95, Gemmeiza-7, Gemmeiza-9, Gemmeiza-10, Gemmeiza-11, Gemmeiza12 , and Shandweel-1, was verified with a DNA fragment of $1100 \mathrm{bp}$ (Fig.1).

\section{Discussion}

Wheat stripe rust epidemics usually occur due to new virulent races and favorable weather conditions. The constant change of $P$. striiformis $\mathrm{f}$. sp. tritici populations is mainly due to the long-distance migration, high mutation, somatic recombination, and selection of the cultivars (Wan et al., 2004; Chen, 2005; Lei et al., 2017). Conventionally, breeders select wheat lines having strong all-stage resistance, which is controlled by a major gene and easy to be incorporated into new cultivars. Nevertheless, all-stage resistance is mostly race-specific, and new virulent races can easily overcome this. Widely growing of cultivars with racespecific resistance lead to new virulent races may become widespread and cause large-scale epidemics. In this case, we studied race-specificity of stripe rust resistance genes responsible for the susceptibility of Egyptian wheat cultivars during two growing seasons (2017/18 and 2018/19). Field evaluation revealed high levels of adult plant susceptibility in 2018/19 second season in comparison with that of 2017/18 first season. In 2018/19 season, it was recorded h 14 cultivars ranging between $30 \mathrm{~S}-90 \mathrm{~S}$, and 7 race-specific resistance genes $(\mathrm{Yr})$ rating $20 \mathrm{MS}-80 \mathrm{~S}$. However, it was recorded with only 8 cultivars and $4 \mathrm{Yr}$ genes $(10 \mathrm{~S}$ $80 \mathrm{~S}$ ) in $2017 / 18$ season. 
Table 4 Adult plant reaction of wheat lines carrying race- specific resistance genes $(Y r)$ and Egyptian wheat cultivars against stripe rust under field condition

\begin{tabular}{|c|c|c|}
\hline \multirow{2}{*}{ Cultivar } & \multicolumn{2}{|c|}{ Adult plant reaction } \\
\hline & 2017/18 season & 2018/19 season \\
\hline Kalyasona & $10 \mathrm{MR}$ & $20 \mathrm{MS}$ \\
\hline Hybrid-46 & 0 & 0 \\
\hline Yr6/6*AOC & $40 \mathrm{~S}$ & $60 \mathrm{~S}$ \\
\hline Yr7/6*AOC & $80 \mathrm{~S}$ & $80 \mathrm{~S}$ \\
\hline $\operatorname{Yr} 8 / 6 * \mathrm{AOC}$ & $5 \mathrm{MR}$ & $20 \mathrm{MS}$ \\
\hline $\operatorname{Yr} 9 / 6 * A O C$ & $60 \mathrm{~S}$ & $80 \mathrm{~S}$ \\
\hline $\operatorname{Yr} 10 / 6 * A O C$ & 0 & 0 \\
\hline TP1295 & $10 \mathrm{MR}$ & $30 \mathrm{~S}$ \\
\hline Yr27/6*AOC & $10 \mathrm{~S}$ & $30 \mathrm{~S}$ \\
\hline Misr-1 & $\operatorname{Tr} M R$ & $80 \mathrm{~S}$ \\
\hline Misr-2 & $\operatorname{Tr} \mathrm{R}$ & $70 \mathrm{~S}$ \\
\hline Misr-3 & $\operatorname{Tr} M R$ & $10 \mathrm{MR}$ \\
\hline Sids-12 & $80 \mathrm{~S}$ & $90 \mathrm{~S}$ \\
\hline Sids-13 & $30 \mathrm{MS}$ & $30 \mathrm{~S}$ \\
\hline Sakha-61 & $10 \mathrm{~S}$ & $30 \mathrm{~S}$ \\
\hline Sakha-93 & $10 \mathrm{MR}$ & $20 \mathrm{MR}$ \\
\hline Sakha-94 & $20 \mathrm{MR}$ & $30 \mathrm{MR}$ \\
\hline Sakha-95 & $5 \mathrm{MR}$ & $10 \mathrm{MR}$ \\
\hline Gemmeiza-5 & $10 \mathrm{MR}$ & $30 \mathrm{~S}$ \\
\hline Gemmeiza-7 & $30 \mathrm{~S}$ & $40 \mathrm{~S}$ \\
\hline Gemmeiza-9 & $30 \mathrm{~S}$ & $40 \mathrm{~S}$ \\
\hline Gemmeiza-10 & $40 \mathrm{~S}$ & $50 \mathrm{~S}$ \\
\hline Gemmeiza-11 & $30 \mathrm{~S}$ & $90 \mathrm{~S}$ \\
\hline Gemmeiza-12 & $10 \mathrm{MR}$ & $40 \mathrm{~S}$ \\
\hline Giza-163 & $50 \mathrm{~S}$ & $60 \mathrm{~S}$ \\
\hline Giza-167 & $30 \mathrm{MR}$ & $30 \mathrm{~S}$ \\
\hline Giza-168 & $10 \mathrm{MR}$ & $20 \mathrm{MR}$ \\
\hline Giza-171 & $10 \mathrm{MR}$ & $10 \mathrm{MR}$ \\
\hline Shandweel-1 & $30 \mathrm{MR}$ & $70 \mathrm{~S}$ \\
\hline Morocco & $80 \mathrm{~S}$ & $90 \mathrm{~S}$ \\
\hline
\end{tabular}

Kalyasona: Yr2, Hybrid-46: Yr4, TP1295: Yr25, AOC: Avocet NILs with $Y r 6, Y r 7, Y r 8, Y r$ 9, $Y r 10, Y r 27,0$ : No Symptoms, R: Resistant, MR:Moderately Resistant, MS: Moderately Susceptible, S: Susceptible
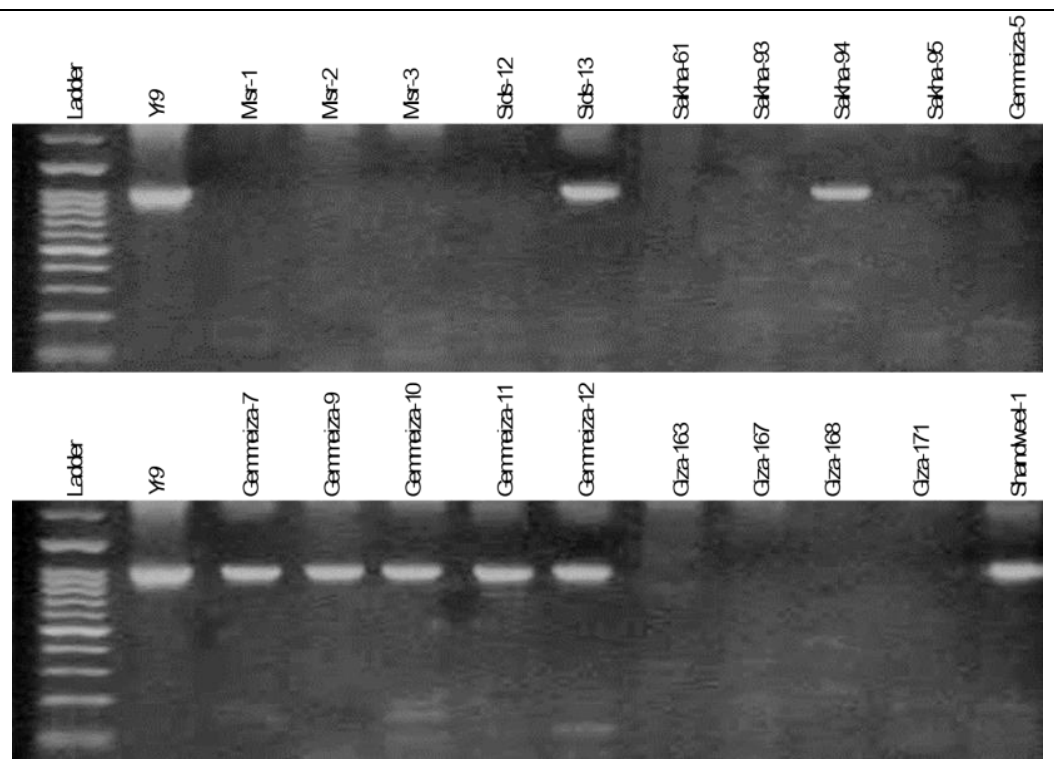

Fig.1 PCR of the STS marker iag-95 indicate the presence of races specific gene $Y r 9$ in eight Egyptian wheat cultivars with a DNA fragment of 1100-bp 
Table 5 Seedling response of wheat lines carrying race-specific resistance genes $(\mathrm{Yr})$ and Egyptian wheat cultivars to 12 races of Puccinia striiformis f. sp. tritici (Pst) and postulated genes.

\begin{tabular}{|c|c|c|c|c|c|c|c|c|c|c|c|c|c|}
\hline \multirow[b]{2}{*}{ Cultivar } & \multicolumn{12}{|c|}{ Pst races/response } & \multirow[b]{2}{*}{$\begin{array}{c}\text { Postulated } \\
\text { Yr gene }\end{array}$} \\
\hline & 0E16 & $2 \mathrm{EO}$ & $4 \mathrm{EO}$ & $64 \mathrm{EO}$ & $66 \mathrm{E} 0$ & $70 \mathrm{E} 4$ & $6 \mathrm{E} 4$ & 2E16 & $4 \mathrm{E} 130$ & PstS2 & PstS3 & $\begin{array}{c}\text { Triticale } \\
\text { aggressive }\end{array}$ & \\
\hline Kalyasona & $\mathrm{R}$ & $\mathrm{R}$ & $\mathrm{S}$ & $\mathrm{R}$ & $\mathrm{R}$ & $S$ & $S$ & $\mathrm{R}$ & $\mathrm{S}$ & $\mathbf{S}$ & $\mathbf{S}$ & $\mathbf{S}$ & $Y r 2$ \\
\hline Hybrid-46 & $\mathrm{R}$ & $\mathrm{R}$ & $\mathrm{R}$ & $\mathrm{S}$ & $\mathrm{S}$ & $\mathrm{S}$ & $\mathrm{R}$ & $\mathrm{R}$ & $\mathrm{R}$ & $\mathrm{R}$ & $\mathrm{R}$ & $\mathrm{R}$ & Yr4 \\
\hline Yr6/6*AOC & $\mathrm{R}$ & $\mathrm{R}$ & $\mathrm{S}$ & $\mathrm{R}$ & $\mathrm{R}$ & $\mathrm{S}$ & $\mathrm{S}$ & $\mathrm{R}$ & $\mathrm{S}$ & $\mathrm{S}$ & $\mathrm{S}$ & $\mathrm{S}$ & Yr6 \\
\hline Yr7/6*AOC & $\mathrm{R}$ & S & $\mathrm{R}$ & $\mathrm{R}$ & S & S & S & S & S & S & S & $S$ & $Y r 7$ \\
\hline Yr8/6*AOC & S & $\mathrm{R}$ & $\mathrm{R}$ & $\mathrm{R}$ & $\mathrm{R}$ & $\mathrm{R}$ & $\mathrm{R}$ & S & $\mathrm{R}$ & S & S & $S$ & $\operatorname{Yr} 8$ \\
\hline Yr9/6*AOC & $\mathrm{R}$ & $\mathrm{R}$ & $\mathrm{R}$ & $\mathrm{R}$ & $\mathrm{R}$ & $\mathrm{R}$ & $\mathrm{R}$ & $\mathrm{R}$ & $\mathrm{R}$ & $\mathrm{S}$ & $\mathrm{R}$ & $\mathrm{R}$ & $\operatorname{Yr} 9$ \\
\hline Yr10/6*AOC & $\mathrm{R}$ & $\mathrm{R}$ & $\mathrm{R}$ & $\mathrm{R}$ & $\mathrm{R}$ & $\mathrm{R}$ & $\mathrm{R}$ & $\mathrm{R}$ & $\mathrm{R}$ & $\mathrm{R}$ & $\mathrm{R}$ & $\mathrm{S}$ & Yr10 \\
\hline TP1295 & $\mathrm{R}$ & $\mathrm{R}$ & $\mathrm{R}$ & $\mathrm{R}$ & $\mathrm{R}$ & $\mathrm{S}$ & $\mathrm{S}$ & $\mathrm{R}$ & $\mathrm{S}$ & $\mathrm{S}$ & $\mathrm{S}$ & $\mathrm{R}$ & Yr25 \\
\hline Yr27/6*AOC & $\mathrm{R}$ & $\mathrm{R}$ & $\mathrm{R}$ & $\mathrm{R}$ & $\mathrm{R}$ & $\mathrm{R}$ & $\mathrm{R}$ & $\mathrm{R}$ & $\mathrm{R}$ & $\mathrm{S}$ & $\mathrm{R}$ & $\mathrm{R}$ & Yr27 \\
\hline Misr-1 & $\mathrm{S}$ & $\mathrm{S}$ & $\mathrm{S}$ & $\mathrm{S}$ & $\mathrm{S}$ & $\mathrm{S}$ & $S$ & $\mathrm{~S}$ & $\mathrm{~S}$ & $\mathrm{R}$ & $\mathrm{S}$ & $\mathrm{S}$ & - \\
\hline Misr-2 & $\mathrm{S}$ & $\mathrm{S}$ & $\mathrm{S}$ & $\mathrm{S}$ & $\mathrm{S}$ & $\mathrm{S}$ & $\mathrm{S}$ & $\mathrm{S}$ & $\mathrm{S}$ & $\mathrm{R}$ & $\mathrm{S}$ & $\mathrm{S}$ & - \\
\hline Misr-3 & $\mathrm{R}$ & $\mathrm{R}$ & $\mathrm{R}$ & $\mathrm{R}$ & $\mathrm{R}$ & $\mathrm{S}$ & $\mathrm{R}$ & $\mathrm{R}$ & $\mathrm{R}$ & $\mathrm{R}$ & $\mathrm{R}$ & $\mathrm{R}$ & - \\
\hline Sids-12 & $\mathrm{S}$ & $\mathrm{S}$ & $\mathrm{S}$ & $\mathrm{S}$ & $\mathrm{S}$ & $\mathrm{S}$ & $\mathrm{S}$ & $\mathrm{S}$ & $\mathrm{S}$ & $\mathrm{R}$ & $\mathrm{S}$ & $\mathrm{S}$ & - \\
\hline Sids-13 & $\mathrm{R}$ & $\mathrm{R}$ & $\mathrm{R}$ & $\mathrm{R}$ & $\mathrm{R}$ & $\mathrm{R}$ & $\mathrm{R}$ & $\mathrm{R}$ & $\mathrm{R}$ & $S$ & $\mathrm{R}$ & $\mathrm{R}$ & $\operatorname{Yr} 9$ \\
\hline Sakha-61 & $\mathrm{S}$ & $\mathrm{S}$ & $\mathrm{S}$ & $\mathrm{S}$ & $\mathrm{R}$ & $\mathrm{S}$ & $\mathrm{S}$ & $\mathrm{S}$ & $\mathrm{S}$ & $\mathrm{R}$ & $\mathrm{S}$ & $\mathrm{S}$ & - \\
\hline Sakha-93 & $S$ & $S$ & $\mathrm{~S}$ & S & $\mathrm{S}$ & $S$ & $S$ & S & S & $\mathrm{R}$ & S & $S$ & - \\
\hline Sakha-94 & $\mathrm{R}$ & $\mathrm{R}$ & $\mathrm{R}$ & $\mathrm{R}$ & $\mathrm{R}$ & $\mathrm{R}$ & $\mathrm{R}$ & $\mathrm{R}$ & $\mathrm{R}$ & S & $\mathrm{R}$ & $\mathrm{R}$ & $\operatorname{Yr} 9$ \\
\hline Sakha-95 & $\mathrm{R}$ & $\mathrm{R}$ & $\mathrm{R}$ & $\mathrm{R}$ & $\mathrm{R}$ & $\mathrm{S}$ & $\mathrm{R}$ & $\mathrm{R}$ & $\mathrm{R}$ & $\mathrm{R}$ & $\mathrm{S}$ & $\mathrm{R}$ & - \\
\hline Gemmeiza-5 & $\mathrm{S}$ & $\mathrm{S}$ & $\mathrm{S}$ & $\mathrm{S}$ & $\mathrm{S}$ & $\mathrm{S}$ & $\mathrm{S}$ & $\mathrm{S}$ & $\mathrm{S}$ & $\mathrm{S}$ & $\mathrm{S}$ & $\mathrm{S}$ & - \\
\hline Gemmeiza-7 & $\mathrm{R}$ & $\mathrm{R}$ & $\mathrm{R}$ & $\mathrm{R}$ & $\mathrm{R}$ & $\mathrm{R}$ & $\mathrm{R}$ & $\mathrm{R}$ & $\mathrm{R}$ & $\mathrm{S}$ & $\mathrm{R}$ & $\mathrm{R}$ & $\operatorname{Yr} 9$ \\
\hline Gemmeiza-9 & $\mathrm{R}$ & $\mathrm{R}$ & $\mathrm{R}$ & $\mathrm{R}$ & $\mathrm{R}$ & $\mathrm{R}$ & $\mathrm{R}$ & $\mathrm{R}$ & $\mathrm{R}$ & $\mathrm{S}$ & $\mathrm{R}$ & $\mathrm{R}$ & $Y r 9$ \\
\hline Gemmeiza-10 & $\mathrm{R}$ & $\mathrm{R}$ & $\mathrm{R}$ & $\mathrm{R}$ & $\mathrm{R}$ & $\mathrm{R}$ & $\mathrm{R}$ & $\mathrm{R}$ & $\mathrm{R}$ & $\mathrm{S}$ & $\mathrm{R}$ & $\mathrm{R}$ & $\operatorname{Yr} 9$ \\
\hline Gemmeiza-11 & $\mathrm{R}$ & $\mathrm{R}$ & $\mathrm{R}$ & $\mathrm{R}$ & $\mathrm{R}$ & $\mathrm{R}$ & $\mathrm{R}$ & $\mathrm{R}$ & $\mathrm{R}$ & S & $\mathrm{R}$ & $\mathrm{R}$ & $\operatorname{Yr} 9$ \\
\hline Gemmeiza-12 & $\mathrm{R}$ & $\mathrm{R}$ & $\mathrm{R}$ & $\mathrm{R}$ & $\mathrm{R}$ & $\mathrm{R}$ & $\mathrm{R}$ & $\mathrm{R}$ & $\mathrm{R}$ & S & $\mathrm{R}$ & $\mathrm{R}$ & $\operatorname{Yr} 9$ \\
\hline Giza-163 & $\mathrm{S}$ & $\mathrm{S}$ & $\mathrm{S}$ & $\mathrm{S}$ & $\mathrm{S}$ & $\mathrm{S}$ & $\mathrm{S}$ & $\mathrm{S}$ & $\mathrm{S}$ & $\mathrm{R}$ & $\mathrm{S}$ & $\mathrm{S}$ & - \\
\hline Giza-167 & $\mathrm{S}$ & $\mathrm{S}$ & $\mathrm{S}$ & $\mathrm{S}$ & $\mathrm{S}$ & $\mathrm{S}$ & $\mathrm{S}$ & $\mathrm{S}$ & $\mathrm{S}$ & $\mathrm{R}$ & $\mathrm{S}$ & $\mathrm{S}$ & - \\
\hline Giza-168 & S & S & S & $\mathrm{R}$ & $\mathrm{R}$ & $S$ & $S$ & S & S & $\mathrm{R}$ & S & $S$ & - \\
\hline Giza-171 & S & S & $\mathrm{S}$ & $\mathrm{R}$ & $\mathrm{R}$ & S & S & $\mathrm{S}$ & $\mathrm{S}$ & $\mathrm{R}$ & $\mathrm{S}$ & $\mathrm{S}$ & - \\
\hline Shandweel-1 & $\mathrm{R}$ & $\mathrm{R}$ & $\mathrm{R}$ & $\mathrm{R}$ & $\mathrm{R}$ & $\mathrm{R}$ & $\mathrm{R}$ & $\mathrm{R}$ & $\mathrm{R}$ & $\mathrm{S}$ & $\mathrm{R}$ & $\mathrm{R}$ & $\operatorname{Yr} 9$ \\
\hline Morocco & $\mathrm{S}$ & $\mathrm{S}$ & $\mathrm{S}$ & $\mathrm{S}$ & $\mathrm{S}$ & $\mathrm{S}$ & $\mathrm{S}$ & $\mathrm{S}$ & $\mathrm{S}$ & $\mathrm{S}$ & $\mathrm{S}$ & $\mathrm{S}$ & - \\
\hline
\end{tabular}

The highest level of susceptibility reaching $90 \mathrm{~S}$ was recorded with cultivars, Sids-12 and Gemmeiza-11, followed by Misr-1 (80 S), Misr-2 (70 S), Giza-163 (60 S) and $Y r$ genes $Y r 7$ and $Y r 9(80 \mathrm{~S})$. Wheat cultivars, Misr-1, Misr-2, Gemmeiza-5, Gemmeiza-12, Giza-167, and Shandweel-1, rated moderately resistance (MR) in 2017/18 season, lost their resistance in the second season (2018/19) with susceptibility up to $80 \mathrm{~S}$ (Misr-1). Cultivars, Misr-3, Sakha-93, Sakha-94, Sakha-95, Giza168 and Giza-171 rated moderately resistance (MR) during both seasons. These findings are in agreement with that of Shahin (2017) who reported that Egyptian cultivars such as Sids-12, Misr-2 and Sakha 61, previously known as resistant to stripe rust, have become susceptible. Also, virulence to several $\mathrm{Yr}$ genes e.g. $\mathrm{Yr} 2$, $\operatorname{Yr} 3 a, Y r 3 b, Y r 4 a, Y r 6, Y r 6+2, Y r 7, \operatorname{Yr} 8, \operatorname{Yr} 9, \operatorname{Yr} 9+2$, $Y r 10, Y r 17, Y r 24, Y r 27, Y r 32, Y r A, Y r C V, Y r S D$ and $\mathrm{YrSU}$, has been reported worldwide, including Egypt (Dawit et al., 2012; Shahin, 2017; Draz, 2019). Dawit et al. (2019) found that the differential lines carrying $Y r 9$, $\mathrm{Yr} 8, \mathrm{Yr} 6$ and $\mathrm{Yr} 7 \mathrm{had}$ the highest rust severity of more than $80 \mathrm{~S}$. Nazari and EL Amil (2013) reported that NILs $Y r 6, Y r 7$, and $Y r 9$ responded with high infection types. The $\operatorname{Yr} 9$ was found among genes that are susceptible to $70-100 \%$ of sixty-one isolates of $P$. striiformis f. sp. tritici (Kumar et al., 2012). The resistance reduction of the most widely grown winter wheat cultivar "Eltan" in the US Pacific Northwest, was due to change of the $P$. striiformis $\mathrm{f}$. sp. tritici population from avirulent to virulent, overcoming the race-specific all-stage resistance (Liu et al., 2019). The evolution of Pst races in Egypt during 2016-2018 has been reported with new virulent races which were used in the present study (Draz et al., 2019; Draz, 2019).

Specificity of host resistance expressed in distinct qualitative seedling reactions, through a challenge with a series of pathogen races, has often formed the basis for genetic analysis and gene postulation of both the host and the pathogen (Day, 1974; Johnson and Knott, 1992). We, therefore, postulated the race-specific resistance genes to stripe rust in 20 Egyptian wheat cultivars, and we tested them together with 12 Pst races at the seedling stage. This set of races represents the contemporary races in Egypt with different origins and virulence spectra to the tested $Y r$ genes, thereby providing useful 
information in relation to cultivar susceptibility. Out of nine $Y r$ genes tested, $Y r 9$ was the commonly encountered gene alone in eight of the cultivars, Sids-13, Sakha 94, Gemmeiza-7, Gemmeiza-9, Gemmeiza-10, Gemmeiza11, Gemmeiza-12 and Shandweel-1. The molecular assay using the STS marker iag95 confirmed the presence of $Y r 9$ in the mentioned cultivars, corresponding to the results of multipathotyping test. This marker has been validated to detect $\operatorname{Yr} 9$ gene in several studies (Mago et al., 2002; Rahmatov et al., 2019). El Amil et al (2019) performed multipathotype test on a collection of wheat elite lines, commercial varieties and landraces from Lebanon and Syria with 11 Pst pathotypes corresponding to $\mathrm{Yrl}, \mathrm{Yr3}, \mathrm{Yr} 4, \mathrm{Yr} 6, \mathrm{Yr} 7$, $\operatorname{Yr} 9, \operatorname{Yr} 17, \operatorname{Yr} 25, \operatorname{Yr} 27, \operatorname{Yr} 32$ and found that all of them except $\operatorname{Yr} 32$ were postulated in wheat accessions. Several studies have reported numerous stripe rust racespecific genes e.g. $Y r 1, Y r 2, Y r 3, Y r 4, Y r 5, Y r 6, Y r 8, Y r 9$, Yr10, Yr15, Yr17, Yr25, Yr26, Yr27, Yr32, YrSel, YrSD, $\mathrm{YrA}$ and $\mathrm{YrSu}$, in different collections of wheat cultivars and lines based on gene postulation and/or in conjugation with molecular markers (Sharma et al., 1995; Hovmøller, 2007; Xia et al., 2007, Wang et al., 2009; Zeng et al., 2014; Gebreslasie et al., 2020). In the current study, we are in the process of screening Egyptian wheat cultivars to identify ineffective genes that have race specificity to the prevailing Pst population in Egypt during 2016-2018. The evaluation of Egyptian wheat cultivars to stripe rust was carried out during 2017-2019 and the susceptibility was recorded with most cultivars tested. Therefore, we anticipate that $\mathrm{Yr}$ racespecific genes, tested to be present in cultivars, may be responsible for the cultivar susceptibility. Gene postulation based on response patterns of cultivars to the prevailing $P s t$ population in Egypt revealed the presence of the $\operatorname{Yr} 9$ gene in the majority of cultivars. We confirmed the presence of the $Y r 9$ gene in cultivars through the reliable marker iag95. Out of eight cultivars, Sids-13, Sakha-94, Gemmeiza-7, Gemmeiza-9, Gemmeiza-10, Gemmeiza11, Gemmeiza-12, and Shandweel-1, that confirmed to possess $Y r 9$ gene with a DNA fragment of 1100-bp, seven cultivars were susceptible to stripe rust except for cultivar Sakha-94 that exhibited moderate resistance. However, five cultivars Misr-3, Sakha-93, Sakha-95, Giza-168 and Giza-171 have moderate resistance to stripe rust during both seasons, but results indicated that they did not possess $\mathrm{Yr} 9$. These findings reveal that high susceptibility of Egyptian cultivars may be attributed to the virulence to $\operatorname{Yr} 9$ gene which was found to be present in susceptible cultivars and absent in moderate resistant cultivars. The common ancestry of Pst population in Egypt was reported to be belonging to three races, including PstS2 (Draz 2019). Our findings revealed that the PstS2 virulence to the gene $Y r 9$ as well as the susceptible Egyptian cultivars was recorded.

The exception of cultivar Sakha-94 being moderately resistant to stripe rust and possessing $\mathrm{Yr} 9$ may be attributed to suppression by a gene or genes in the cultivar Sakha-94. The gene in the heterozygous condition is suppressed by a gene or genes in wheat genome (Chen and Line, 1993). Shahin et al. (2018) reported the presence of adult plant resistance (APR) gene $\mathrm{Yr} 18$ in Egyptian cultivar Sakha-94. Therefore, $\mathrm{Yr} 9$ gene present in Sakha-94 may be suppressed due to $\operatorname{Yr} 18$ gene that conferred partial resistance to the cultivar during both seasons. The PstS2 race was first detected in 1980, originated from East Africa remains an important, globally prevalent race (Walter et al., 2016; Ali et al., 2017). It caused severe losses in West and Central Asia in 2003, at a time that the breakdown of the resistance conferred by the widely deployed $\mathrm{Yr} 9$ resistance gene was reported in the region (Singh et al., 2004). The pathotyping of 214 samples collected from the Western Mediterranean region (Portugal, Spain, Southern France, Italy, Morocco, Algeria, Tunisia) and 54 samples from the eastern Mediterranean region (Cyprus, Turkey, Iran, Lebanon) identified 12 pathotypes during 2005-2006, including PstS2 (Bahri et al., 2009). The Pst population in Syria and Lebanon in 2010-2011 was dominated by the PstS2 lineage (El Amil et al., 2020). Thus, this suggests that the Middle East, with its high degree of Pst population diversity, is a hotspot for the emergence of new $P s t$ races. The aggressive, high temperature-adapted race PstS2 virulent to $Y r 9$, was detected between 2000 and 2004 in several European countries but at low frequencies (Hovmoller et al., 2008; de VallavieillePope et al., 2012). The emergence of PstS2 race led the stripe rust pathogen to spread to warmer regions and has become established in Western Australia, New Zealand, Southern and North Africa and the Southern United States (Milus et al. 2006; Wellings, 2011; Chen et al., 2014; Walter et al., 2016). Based on our findings, racespecific resistance gene $\operatorname{Yr} 9$ present in the majority of Egyptian cultivars does not provide protection against stripe rust and may be responsible for the high susceptibility of cultivars. Cultivars carrying $\operatorname{Yr} 9$ should be restricted to use alone in wheat production and be planted match with other genes (Li et al., 2011). In the 
early 2000s, this was the case for the stripe rust epidemics in the United States when virulence to $\operatorname{Yr} 9$ occurred in high frequency (Chen, 2005; Chen et al., 2002). The two most recent epidemics of stripe rust were due to the successive emergence of Pst pathotypes with new virulence factors overcoming the widely used $\operatorname{Yr} 9$ resistance gene (Sharma-Poudyal et al., 2013). More than $80 \%$ of wheat cultivars released in the late 1980s possessed $\operatorname{Yr} 9$ and, as a result, virulence to $\operatorname{Yr} 9$ occurred in 1985 caused stripe rust epidemics that resulted in yield loss of 2.65 million tons in 1990 in China (Chen et al., 2009). Also, the stripe rust epidemic has been reported in 2002 due to the existence of $\operatorname{Yr} 9$ in the wheat cultivars (Wan et al., 2004). The basis for losing resistance in varieties carrying $\mathrm{Yr} 9$ has been reported by Hovmoller (2001). As a result of our investigation, it is revealed that $\operatorname{Yr} 9$ was the most identified gene in the majority of the Egyptian wheat cultivars. The wheat cultivars commercially cultivated in Egypt may have affected by the contemporary Pst races due to the presence of $\operatorname{Yr} 9$.

Resistance singularization is the most important factor causing disease epidemics (Zhu et al., 2000). However, hybridization of the commercial wheat cultivars having a high genetic diversity may not be a logical decision in breeding for resistance, because it could hasten the virulence diversity in Pst population (Draz et al., 2019). Mono-culturing or use of a single resistant gene should be avoided to escape cultivar susceptibility due to stripe rust. Varieties with different resistant genes should be deployed in different wheat-growing regions to ensure sustainable control against stripe rust. Therefore, genetically diverse varieties with pyramiding resistance genes is an effective strategy for disease control (He et al., 2011). Knowledge of race-specific resistance genes to stripe rust in Egyptian wheat cultivars provides important information in designing control measures to develop the resistant wheat germplasm. The high susceptibility of $\operatorname{Yr} 9$ and its presence in the majority of Egyptian cultivars may have evolved from extensive use of $Y r 9$, originating from Petkus rye (Secale cereale), in wheat-breeding programs worldwide (Stubbs, 1985). The emergence and spread of $Y r 9$-virulent races caused serious stripe rust outbreaks in many major wheatgrowing regions (Wan et al., 2004; Chen, 2005; Chen et al., 2002 \& 2009). Our findings suggest that high susceptibility of Egyptian wheat cultivars to stripe rust may be due to the presence of a race-specific gene $\mathrm{Yr}$. Although, cultivars rated moderately resistance in this study may be available options to challenge the disease, however, to escape the infection due to the evolution Pst population, new effective genes for resistance should be incorporated in wheat cultivars.

\section{Conflict of interest}

The authors declare that they have no competing interests.

\section{References}

Ali S, Rodriguez-Algaba J, Thach T, Sørensen CK. Hansen JG. Lassen P, Nazari K, Hodson DP, Justesen AF, Hovmøller MS 2017. Yellow rust epidemics worldwide were caused by pathogen races from divergent genetic lineages. Front. Plant Sci., 8, 1057. doi: 10.3389/fpls.2017.0105

Bahri B, Leconte M, Ouffroukh A, de Vallavieille-Pope C, Enjalbert J 2009. Geographic limits of a clonal population of wheat yellow rust in the Mediterranean region. Mol. Ecol., 18: 4165-4179. doi: 10.1111/j.1365-294X.2009.04267.x

Beddow J, Pardey P, Chai Y, Hurley T, Kriticos D, Braun H, Park R, Cuddy W Yonow T 2015. Research investment implications of shifts in the global geography of wheat stripe rust. Nature Plants, 1 , 15132 https://doi.org/10.1038/nplants.2015.132

Browder LE, Eversmeyer, MG 1980. Sorting of Puccinia recondita: Triticum infection-type data sets toward the gene-for-gene model. Phytopathology, 70:666670. doi:10.1094/Phyto-70-666

Chen W, Wellings C, Chen X, Kang Z, Liu T 2014. Wheat stripe (yellow) rust caused by Puccinia striiformis f. sp. tritici. Mol. Plant Pathol., 15(5): 433-446. doi: 10.1111/mpp.12116

Chen WQ, Wu LR, Liu TG, Xu SC, Jin, SL, Peng, YL, Wang, B.T. 2009. Race dynamics, diversity, and virulence evolution in Puccinia striiformis f. sp. tritici, the causal agent of wheat stripe rust in China from 2003 to 2007. Plant Dis., 93: 1093-1101. https:// doi.org/10.1094/PDIS-93-11-1093 
Chen XM 2005. Epidemiology and control of stripe rust on wheat Puccinia striiformis f. sp. tritici on wheat. Can. J. Plant Pathol., 27:314-337. https://doi.org/10.1080/07060660509507230

Chen, XM 2013. High-temperature adult-plant resistance, key for sustainable control of stripe rust. Am. J. Plant Sci. 4:608-627. doi: 10.4236/ajps.2013.43080

Chen XM, Line RF 1993. Inheritance of stripe rust resistance in eight wheat cultivars postulated to have resistance genes at the $\mathrm{Yr} 3$ and $\mathrm{Yr} 4$ loci. Phytopathology, 83: 382-388. doi: 10.1094/Phyto83-382

Chen XM, Moore MK, Milus EA, Long DL, Line, RF, Marshall D, Jackson L 2002. Wheat stripe rust epidemics and races of Puccinia striiformis f. sp. tritici in the United States in 2000. Plant Dis., 86:39-46. doi.org/10.1094/PDIS.2002.86.1.39

Dawit W, Badebo A, Hunde, B, Kassa, D, Röder MS 2019. Haplotype analysis of Ethiopian bread wheat (Triticum aestivum) cultivars and elite lines for yellow rust resistance genes using linked molecular markers. Afr. J. Biotechnol., 18, (2):37-57. doi.org/10.5897/AJB2018.16539

Dawit W, Flath K, Weber WE, Schumann E, Röder MS Chen X 2012. Postulation and mapping of seedling stripe rust resistance genes in Ethiopian bread wheat cultivars. J. Plant Pathol., 94 (2): 403409.doi.org/10.4454/JPP.FA.2012.040

Day PR 1974. Genetics of Host-Parasite Interactions. Freeman W.H. \& Co., San Francisco, CA, USA

de Vallavieille-Pope C, Ali S, Leconte M, Enjalbert J, Delos Rouzet J. 2012. Virulence dynamics and regional structuring of Puccinia striiformis f. sp. tritici in France between 1984 and 2009. Plant Dis., 96: 131-140. doi: 10.1094/PDIS-02-11-0078

Doyle JJ, Doyle JL 1987. A rapid DNA isolation procedure for small quantities of fresh leaf tissue. Phytochem Bull., 19(1): 11-15
Draz IS 2019. Common Ancestry of Egyptian Puccinia striiformis population along with effective and ineffective resistance genes. Asian J. Biol. Sci., 12: 217-221. doi: 10.3923/ajbs.2019.217.221

Draz IS, Esmail, SM, Abou-Zeid, M, Hafez YM 2018. Changeability in stripe rust infection and grain yield of wheat associated to climatic conditions. Env. Biodiv. Soil Security, 2:143-153. doi: 10.21608/jenvbs.2019.6674.1040

Draz IS, Shahin AA, Esmail SM 2019. Pathotypic and molecular evolution of contemporary population of Puccinia striiformis f. sp. tritici in Egypt during 2016-2018. J. Phytopathol., 167:26-34. doi:10.1111/jph.12770

El Amil, R Ali S, Bahri B, Leconte M, de VallavieillePope, C. Nazari, K 2020. Pathotype diversification in the invasive PstS2 clonal lineage of Puccinia striiformis f. sp. tritici causing yellow rust on durum and bread wheat in Lebanon and Syria in 2010-2011. Plant Pathol., 69:618-630. doi 10.1111/ppa.13164

El Amil R, de Vallavieille-Pope C, Leconte Mm Nazari K 2019. Diversity of genes for resistance to stripe rust in wheat elite lines, commercial varieties and landraces from Lebanon and Syria. Phytopathol. Mediterr., 58 (3): 607-627. doi:10.13128/Phyto10982

El-Daoudi YH, Ikhlas Shafik Ghanem EH Abu El-Naga SA, Sherif SO, Khalifa MMO, Mitkees, R.A. Bassiouni AA 1996. Stripe rust occurrence in Egypt and assessment of grain yield loss in 1995 . Proceedings Du Symposium Regional Sur les Maladies des Cerales et des Legumineuses Alimentaries 11-14 Nov 1996, Rabat, Maroc

Ellis JG, Lagudah ES, Spielmeyer W Dodds PN 2014. The past, present and future of breeding rust resistant wheat. Front. Plant Sci., 5: 641. doi: 10.3389/fpls.2014.0064

Feng JY, Wang MN, See DR Chao SM, Zheng YL, Chen, XM 2018. Characterization of novel gene Yr79 and four additional QTL for all-stage and high-temperature adult-plant resistance to stripe 
rust in spring wheat PI 182103. Phytopathology, 108: 737-747. doi:10.1094/PHYTO-11-17-0375-R

Flor, HH 1959. Genetic controls and host parasite interactions in rust diseases. In: Holton CS (ed.). Plant Pathology, Problems and Progress 19081958, pp. 137-144. University of Wisconsin Press, Madison, WI, USA

Gebreslasie ZS, Huang S, Zhan G, Badebo A, Zeng Q, Wu J, Wang Q, Liu S, Huang L, Wang X, Kang Z, Han D 2020. Stripe rust resistance genes in a set of Ethiopian bread wheat cultivars and breeding lines. Euphytica, 216: 17. doi.org/10.1007/s10681-019$\underline{2541-\mathrm{Z}}$

He ZH, Xia, XC, Chen XM, Zhuang QS 2011. Progress of wheat breeding in China and the future perspective. Acta Agron. Sin., 37 (2), 202-215 (in Chinese)

Hovmøller MS 2001. Disease severity and pathotype dynamics of Puccinia striiformis f. sp. tritici in Denmark. Plant Pathol., 50: 181-189. doi:10.1046/j.1365-3059.2001.00525.x

Hovmøller MS 2007. Sources of seedling and adult plant resistance to Puccinia striiformis f. sp. tritici in European wheat. Plant Breeding,123:225-233 https://doi.org/10.1111/j.1439-0523.2007.01369.x

Hovmoller MS, Yahyaou, AH, Milus EA, Justesen AF 2008. Rapid global spread of two aggressive strains of a wheat rust fungus. Mol. Ecol., 17: 3818-3826

Johnson R, Knott DR 1992. Specificity in gene-for-gene interactions between plants and pathogens. Plant Pathol., $\quad 41: 1-4 . \quad$ DOI:10.1111/j.13653059.1992.tb02307.x

Kankwatsa P, Singh D, Thomson PC, Babiker EM, Bonman JM, Newcomb M, Park RF 2017. Characterization and genome-wide association mapping of resistance to leaf rust, stem rust and stripe rust in a geographically diverse collection of spring wheat landraces. Mol. Breed., 37, 113. doi: 10.1007/s11032-017-0707-8
Kumar K, Holtz MD, Xi K, Turkington TK 2012. Virulence of Puccinia striiformis on wheat and barley in central Alberta. Can. J. Plant Pathol. 34(4): 551-561. doi: $10.1080 / 07060661.2012 .722130$

Kumar S, Archak S, Tyagi R.K, Kumar J, Vikas V.K, Jacob SR, 2016. Evaluation of 19,460 wheat accessions conserved in the Indian national genebank to identify new sources of resistance to rust and spot blotch diseases. PLoS One, 12:e0175610. doi: 10.1371/journal.pone.0167702

Large EC 1954. Growth stages in cereals. Illustration of the Feekes scale. Plant Pathol, 3: 128-129. https://doi.org/10.1111/j.13653059.1954.tb00716.x

Lei Y, Wang M, Wan A, Xia C, See DR, Zhang M, Chen X 2017. Virulence and Molecular Characterization of experimental isolates of the stripe rust pathogen (Puccinia striiformis) indicate somatic recombination. Phytopathology, 107 (3): 329-344. doi: 10.1094/PHYTO-07-16-0261-R

Li MJ, Feng J, Cao SQ, Lin RM, Cheng G, Yu Y, Chen W, Xu SC 2011. Postulation of seedlings resistance genes to yellow rust in commercial wheat cultivars from Yunnan province in China. Agric. Sci. Chin., 10: $\quad 1723-1731 . \quad$ doi:10.1016/S16712927(11)601715

Liu L, Wang M, Feng J, See DR, Chen X 2019. Wholegenome mapping of stripe rust resistance quantitative trait loci and race specificity related to resistance reduction in winter wheat cultivar Eltan. Phytopathology, 109, (7):1226-1235. doi: 10.1094/PHYTO-10-18-0385-R

Long L, Yao F, Yu C, Ye X, Cheng Y, Wang Y, Wu Y, Li J, Wang J, Jiang Q, Li W, Ma J, Liu Y, Deng M, Wei Y, Zheng Y, Chen G 2019. Genome-wide association study for adult-plant resistance to stripe rust in Chinese wheat landraces (Triticum aestivum L.) from the Yellow and Huai River Valleys. Front Plant Sci., 10:596. doi: 10.3389/fpls.2019.00596

Mago R, Spielmeyer W, Lawrence GJ, Lagudah, ES, Ellis JG, Pryor A 2002. Identification and mapping of molecular markers linked to rust resistance genes 
located on chromosome 1RS of rye using wheat-rye translocation lines. Theor. Appl. Genet. 104 (8): 1317-1324. doi: 10.1007/s00122-002-0879-3

McIntosh RA, Dubcovsky J, Rogers WJ, Morris C, Appels R, Xia XC 2017. Catalogue of Gene Symbols for Wheat: 2017 Supplement. Available online: http://shigen.nig.ac.jp/wheat/komugi/genes/macgen e/ supplement2017.pdf

McNeal FH, Konzak CF, Smith EP, Tate WS, Russell TS 1971. A uniform system for recording and processing cereal research data. USDA Agric. Res. Ser. Bull, 42, 34-121

Milus EA, Seyran E, McNew R. 2006. Aggressiveness of Puccinia striiformis f. sp. tritici isolates in the South-Central United States. Plant Dis., 90, 847852. doi:10.1094/PD-90-0847

Nazari K, ELAmil R 2013. First report of resistance of wheat line Avocet ' $S$ ' to stripe rust caused by Puccinia striiformis f. sp. tritici (Pst) in Syria. Plant Dis., 97 (7): 996. doi: 10.1094/PDIS-11-12-1109PDN

Nsabiyera V, Bariana HS, Qureshi N, Wong D, Hayden M.J. Bansal UK 2018. Characterization and mapping of adult plant stripe rust resistance in wheat accession Aus7284.Theor. Appl. Genet., 131, 1-9. doi: 10.1007/s00122-018-3090-x

Peterson RF, Campbell AB, Hannah AE 1948. A diagrammatic scale for estimating rust severity on leaves and stems of cereals. Can. J. Genet. Cytol., 26:496-500. https://doi.org/10.1139/cjr48c-033

Pink DAC 2002. Strategies using genes for non-durable disease resistance. Euphytica, 124: 227-236. https://doi.org/10.1023/A:1015638718242

Rahmatov M, Otambekova M, Muminjanov H, Rouse, MN, Hovmøller MS, Nazari K, Steffenson, BJ, Johansson E 2019. Characterization of stem, stripe and leaf rust resistance in Tajik bread wheat accessions. Euphytica, 215: 55. https://doi.org/10.1007/s10681-019-2377
Roelfs AP, Singh RP, Saari EE 1992. Rust Diseases of Wheat: Concepts and Methods of Disease Management. CIMMYT, Mexico. $81 \mathrm{p}$

Shahin AA, Omar Hend A, El-Sayed AB 2018. Characterization of $\mathrm{Yr} 18 / \mathrm{Lr} 34$ partial resistance gene to yellow rust in some Egyptian wheat cultivars. Egy. J. Plant Pro. Res., 6 (3):1-9

Shahin AA 2017. Effective genes for resistance to wheat yellow rust and virulence of Puccinia striiformis $\mathrm{f}$. sp. tritici in Egypt. Egypt. Acad. J. Biol. Sci., 8 (2): 1-10. doi: 10.21608/EAJBSH.2017.16762

Sharma, S.; Louwers, J.M.; Karki C.B. and Snijders C.H.A. 1995. Postulation of resistance genes to yellow rust in wild emmer wheat derivatives and advanced wheat lines from Nepal. Euphytica, 81: 271-277. https://doi.org/10.1007/BF00025617

Sharma-Poudyal D, Chen XM, Wan AM, Zhan GM, Kang ZS, Patzek LJ 2013. Virulence characterization of international collections of the wheat stripe rust pathogen, Puccinia striiformis $\mathrm{f}$. sp. tritici. Plant Dis, 97: 379-386. http://dx.doi.org/10.1094/ PDIS-01-12-0078-RE

Singh RP, William HM, Huerta-Espino J, Rosewarne G 2004. Wheat rust in Asia: meeting the challenges with old and new technologies. Proceedings of the 4th International Crop Science Conference, 26 Sep. - 1 Oct., 2004. Brisbane, Australia

Statler GD 1984. Probable genes for leaf rust resistance in several hard red spring wheats. Crop Sci., 24:883-886.

https://doi.org/10.2135/cropsci1984.0011183X0024 $\underline{00050013 \mathrm{x}}$

Stubbs RW 1985. Stripe rust. In: The Cereal Rusts II. Diseases, Distribution, Epidemiology and Control. A.P. Roelfs and W.R. Bushnell, eds. Academic Press, pp 61-101, New York

Stubbs RW 1988. Pathogenicity analysis of yellow (stripe) rust of wheat and its significance in global context. In: Simmonds NW, Rajaram S (eds). Breeding Strategies for Resistance to Rusts of Wheat, pp. 96-127. CIMMYT, Mexico 
Walter S, Ali S, Kemen E, Nazari K, Bahri BA, Enjalbert J, Hansen JG, Brown, JKM, SicheritzPontén, T, Jones J, de Vallavieille-Pope, C, Hovmøller, MS, Justesen AF 2016. Molecular markers for tracking the origin and worldwide distribution of invasive strains of Puccinia striiformis. Ecol. Evol., 6: 2790-2804. doi: 10.1002/ece3.2069

Wan A, Zhao Z, Chen, X, He Z, Jin, S, Jia, Q, Yao, G, Yang J, Wang, B, Li, G, Bi, Y, Yuan Z. 2004. Wheat stripe rust epidemic and virulence of Puccinia striiformis f. sp. tritici in China in 2002. Plant Dis., 88:896-904. https://doi.org/10.1094/PDIS.2004.88.8.896

Wan AM, Chen XM, He ZH 2007. Wheat stripe rust in China. Aust. J. Agric. Res., 58: 605-619. https://doi.org/10.1071/AR06142

Wang, L.M.; Zhang, Z.Y.; Liu, H.J.; Xu, S.C.; He, M.Z.; Liu, H.X.; Veisz, O. and Xin, Z.Y. 2009. Identification, gene postulation and molecular tagging of a stripe rust resistance gene in synthetic wheat CI142. Cereal Res. Commun., 37 (2): 20915. https://doi.org/10.1556/CRC.37.2009.2.7

Wang M, Chen XM 2017. Stripe rust resistance In: Stripe Rust (eds) XM, Chen ZS, Kang (Berlin: Springer), 353-558. doi: 10.1007/978-94-0241111-9

Wellings CR 2011. Global status of stripe rust: A review of historical and current threats. Euphytica, 179, 129-141. $\quad$ https://doi.org/10.1007/s10681-011$0360 \mathrm{y}$

Xia XC, Li ZF, Li GQ, Singh RP 2007. Stripe rust resistance in Chinese bread wheat cultivars and lines. In: Buck HT, Nisi JE, Salomon N (eds). Wheat Production in Stressed Environments, pp. 77-82. Springer, Amsterdam, The Netherlands

Xu LS, Wang MN, Cheng P, Kang, ZS, Hulbert SH, Chen XM 2013. Molecular mapping of Yr53, a new gene for stripe rust resistance in durum wheat accession PI480148 and its transfer to common wheat. Theor. Appl. Genet., 126:523-533. https://doi.org/10.1007/s00122-012-1998-0
Yang E, Li G, Li L, Zhang Z, Yang W, Peng Y, Zhu Y, Yang Z, Rosewarne GM 2016. Characterization of stripe rust resistance genes in the wheat cultivar Chuanmai 45. Int. J. Mol. Sci., 21, 17(4):601. doi: 10.3390/ijms 17040601

Yang, M, Li G, Wan H, Li L, Li J, Yang W, Pu Z, Yang Z, Yang E 2019. Identification of QTLs for stripe rust resistance in a recombinant inbred line population. Int. J. Mol. Sci., 20: 3410. https://doi.org/10.3390/ijms20143410

Zeng Q, Han D, Wang Q, Yuan F, Wu J, Zhang L, Wang X, Huang L, Chen X, Kang Z 2014. Stripe rust resistance and genes in Chinese wheat cultivars and breeding lines. Euphytica, 196: 271-284. doi:10.1007/s10681-013-1030-z

Zheng SG, Li YF, Lu L, Liu ZH, Zhang CH, Ao DH, Li LR, Zhang CY, Liu R, Luo CP, Wu Y, Lei Z 2017. Evaluating the contribution of $\mathrm{Yr}$ genes to stripe rust resistance breeding through marker assisted detection in wheat. Euphytica, 213:50. doi:10.1007/s10681-016-1828-6

Zhou XL, Han DJ, Chen XM, Gou HL, Guo SJ, Rong L, Wang QL, Huang LL, Kang ZS 2014. Characterization and molecular mapping of stripe rust resistance gene Yr61 in winter wheat cultivar Pindong 34. Theor. Appl. Genet., 127: 2349-2358. https://doi.org/10.1007/s00122-014-2381-0

Zhu YY, Chen HR, Fan JH, Wang YY, Li Y, Chen JB, Fan JX, Yang SS, Hu LP, Leung H, Mew TW, Teng PS, Wang ZH, Mundt CC 2000. Genetic diversity and disease control in rice. Nature, 406 (6797):718-722. doi: 10.1038/35021046 